\title{
The Characteristics of Air Pollutants Distribution Around Industrial Complexes Using Real-Time Mobile Atmospheric Measurement System
}

\author{
Seongwoo Choi $^{\oplus} \cdot$ Seungwoo Park $^{\oplus} \cdot$ Youngwook Cha $^{\oplus} \cdot$ Seoi Lee ${ }^{\oplus} \cdot$ Eunchul Yoo $^{\curvearrowleft}$
}

Busan Metropolitan City Institute of Health \& Environment

(Received April 13, 2021; Revised June 2, 2021; Accepted June 11, 2021)

Objectives: Volatile organic compounds discharged from industrial complexes need to be managed. They make $\mathrm{PM}, \mathrm{O}_{3}$ etc from NOx and photochemical reaction in the atmosphere and become a major source of odor.

Methods: The environmental impacts around Sasang industrial area and Shinpyeong-Jangrim general industrial complex were investigated by SIFT-MS, which can continuously real-time measure air pollutants such as volatile organic compounds. A map of air pollution around industrial complexes was drawn up and major impact substances were identified.

Results and Discussion: Benzene was all within the atmospheric standard and hexane was the highest concentration. Alkane, aldehyde and alcohol groups were relatively high in Sasang industrial area. Amide and thiol groups were relatively high in Shinpyeong-Jangrim general industrial complex. Most of volatile organic compounds were high in May, and some odorous substances were high in summer. The pollution map of Sasang industrial area was high around Nakdong-daero and Gamjeoncheon. And the pollution map of Shinpyeong-Jangrim general industrial complex was various according to the source of discharge, but the northern point with dyeing wastewater treatment plant was relatively high. The correlation between PM-2.5 and VOCs was investigated at a low value, and further research on fixed points should be conducted.

Conclusions: As a result of analyzing 84 types of SIFT-MS and 2 types of OPC, most items in Sasang industrial area were higher concentration than those in Shinpyeong-Jangrim general industrial complex.

Keywords: Particulate Matter, SIFT-MS, Odorous Substances, VOCs

The Korean text of this paper can be translated into multiple languages on the website of http://jksee.or.kr through Google Translator.

Corresponding author
E-mail: choisw7931@korea.kr
Tel: 051-309-2924 Fax: 051-309-2939
(c) 2021, Korean Society of Environmental Engineers

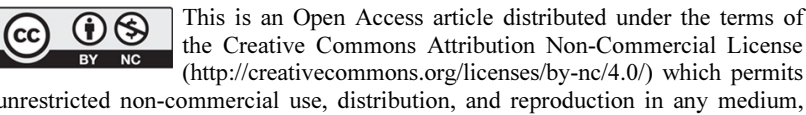
unrestricted non-commercial use, distribution, and reproduction in any medium, provided the original work is properly cited. 


\title{
연구논문
}

\section{실시간 대기이동측정시스템을 이용한 산업단지 주변 대기오염물질 분포 특성}

\author{
최성우 ${ }^{\circledR} \cdot$ 박승우 $^{\circledR} \cdot$ 차영욱 $^{\circledR} \cdot$ 이서이 $^{\circledR} \cdot$ 유은철 $^{\circledR}$ \\ 부산광역시 보건환경연구원
}

목적: 산업단지에서 배출되는 휘발성유기화합물은 대기 중에서 질소산화물과 광화학반응을 하여 미세먼지와 오존 등을 생성시키는 전구물질이며, 악취 발생의 주원인으로 관리가 필요하다.

방법: VOCs 등 대기오염물질의 연속 실시간 측정가능한 SIFT-MS를 활용하여 사상공업지역과 신평·일반산업단지 주변 환경영향을 조사하고, 산업단지 주변 대기오염물질 오염지도를 작성하여 주요 영향물질을 파악하였다.

결과 및 토의 : 대기환경기준 물질인 벤젠은 모두 대기환경기준 이내이며, 헥산이 최고농도로 나타났다. 사상공업지 역은 알칸, 알데하이드, 알콜계열의 화학물질이 상대적으로 높게 나타났고, 신평·장림일반산업단지는 아미드, 티올 계열의 화학물질이 상대적으로 높게 나타났다. VOCs 대부분은 5 월에 높게 측정되었고, 일부 악취물질은 여름에 높게 측정되었다. 사상공업지역의 오염지도는 낙동대로와 감전천 주변의 오염도가 높게 나타났고, 신평·장림일반 산업단지의 오염지도는 배출원에 따라 다양하게 나타났으나, 염색폐수처리장이 있는 북쪽지점이 상대적으로 높게 나타났다. PM-2.5와 VOCs 농도분포의 상관관계는 낮은 값으로 조사되었고, 도로를 이용한 이동측정보다 고정지점 을 통한 추가연구가 진행되어야 할 것으로 판단된다.

결론 : SIFT-MS 84종, OPC 2종 분석결과 사상공업지역이 신평·장림일반산업단지 보다 대부분 항목이 상대적으로 높은 농도값을 나타내었다.

주제어: 미세먼지, 선택적다중이온질량분석기, 악취물질, 휘발성유기화합물

\section{1. 서론}

부산의 사상공업지역은 1960 년대 공업지역으로 지정된 후 신발, 조립금속, 기계장비, 주물 등 부산 최대의 공업지역으로 성장하였으나, 1990년대 이후 전통적 주력산업이 쇠퇴하고 기반시설의 노후화로 산업입지 경쟁력이 저하되고 있다. 이에 국토해양부에서 “산업단지재생사업”을 제도화하여 노후공업 지역 재생을 통한 산업기능 회복을 진행하고 있다. 부산의 산 업단지는 1984년 신평·장림일반산업단지를 최초로 조성한 이래 2020년 현재 국가산업단지 1개소, 일반산업단지 30 개소, 도시첨단산업단지 4 개소, 농공단지 1 개소로 총 4,394 만 $^{2}$ 의 지정면적을 가지고 있으며, 강서구와 기장군, 사하구, 해운대 구, 금정구에 분포되어 있다. ${ }^{1)}$ 특히 신평·장림일반산업단지 는 281 만m²으로 도금, 피혁, 염색, 기계부품, 일반제조업 등이 입주하여 각종 화학물질이 다양하게 배출되어 주위 환경에 영향을 미치고 있는 실정이다. 산업단지의 경우 미세먼지와 유해 화학물질 배출로 인해 인근 주민 건강에 악영향이 우려
되고 있으므로, 부산과 같이 대규모 산업단지가 있는 지역의 경우 산업단지주변 대기오염물질 오염지도를 작성하여 주요 한 오염원을 파악하고 지역의 오염물질 배출과 건강영향에 대한 조사가 필요하다.

산업단지에서 배출되는 휘발성유기화합물(Volatile Organic Compounds; VOCs)과 질소산화물(NOx)은 오존 $\left(\mathrm{O}_{3}\right)$ 생성의 원인물질이며, 오존은 산화제로 작용하여 $\mathrm{NOx}$ 및 황산화물 (SOx)을 미세먼지와 같은 2차 생성유기입자로 만드는 원인물 질로 알려져 있다. VOCs 중 독성이 강한 할로겐화탄화수소류 와 방향족탄화수소류 등은 발암물질로 돌연변이를 유발하고 장기간 노출 시 감각기관의 자극이나 천식 등과 같은 인체에 유해한 피해를 일으킨다. ${ }^{2)}$ 이에 환경부에서는 대기환경관리 를 위해 2000년대부터 광화학오염물질 측정망과 유해대기오 염물질 측정망을 통해 대기 중 VOCs 농도를 측정하고 있으 나, 국내에서는 대부분 무해한 비메탄계 탄화수소류가 주를 이루며, 독성이 강한 할로겐화 VOCs 물질에 대해서는 7종만 측정하고 있어 다양한 위해성평가를 수행하기에는 정보가 부 

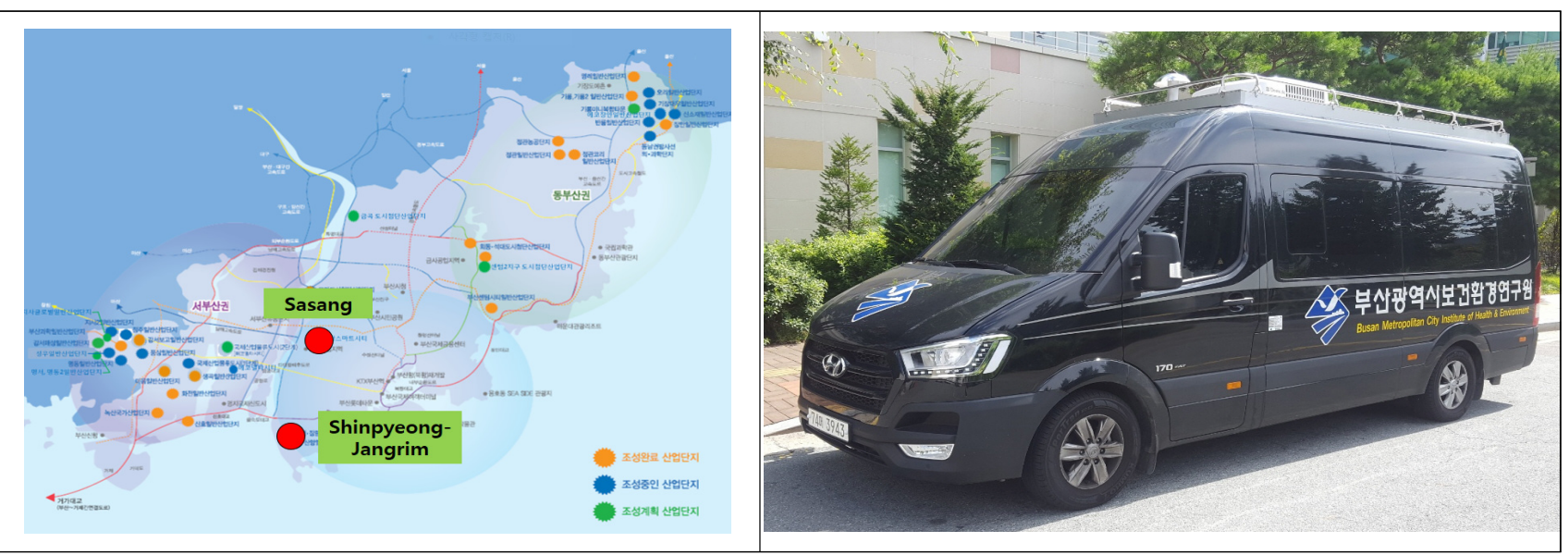

Fig. 1. Location of the sampling sites and real-time mobile atmospheric measurement system.

족하다. ${ }^{3)}$

최근 시료채취 및 전처리과정 없이 대기 중에 있는 VOCs 를 direct injection을 통해 실시간으로 연속 측정할 수 있는 선택적다중이온질량분석기(Selected Ion Flow Tube Mass Spectrometry ; SIFT-MS)등이 개발되었다.,5) SIFT-MS는 GC (Gas Chromatography)-MS에서 사용하는 칼럼(Column)을 사 용한 물리적 분리 대신 8가지 Reagent ion의 반응을 이용하여 8 가지 Matrix를 통한 화학적 분리로 대기중에 있는 VOCs나 무기가스(Inorganic gases)를 실시간으로 정성·정량 분석할 수 있는 질량 분석기이다. 수분의 영향을 받지 않으며, 별도의 시료 농축 없이 pptv level까지 분석이 가능한 장점으로 작업 환경 유해물질 분석, 부지경계선 악취물질분석, 건축물 및 자 동차 실내공기 분석 등 다양한 분야에 적용되고 있다. ${ }^{5-9)}$ 최근 대기환경분야에도 활용되고 있으나, 아직까지 산업단지 대기 중 VOCs에 대한 분석연구는 제한된 지역에서 수행되었기 때 문에 연구결과가 부족한 수준이다.

따라서, 본 연구는 부산지역 산업단지 중 비교적 규모가 크고 노후화된 사상공업지역과 신평·장림일반산업단지를 선정하여 대기 중 $\mathrm{VOCs}$ 와 입자상물질 등 대기오염물질을 SIFT-MS와 광학입자계수기(Optical Particle Counter; OPC)를 탑재한 대기이동측정시스템으로 연속 실시간 측정하여 주요 산업단지 주변 환경영향조사와 주변 지역에 미치는 영향을 연구하고자 한다.

\section{2. 실험방법}

\section{1. 연구기간 및 대상시설}

본 연구는 시운전을 포함하여 2019년 1월부터 12월까지 진 행되었고, Fig.1과 같이 부산지역 산업단지 중 비교적 규모가 크고 노후화된 사상공업지역과 신평·장림일반산업단지를 중 심으로 SIFT-MS 및 $\mathrm{OPC}$ 를 탑재한 실시간 대기이동측정시스 템으로 이동하면서 대기 중 $\mathrm{VOCs}$ 와 입자상물질을 지리정보
시스템(GPS) 자료와 연계하여 20초 간격으로 측정하였다. 배 경농도 비교를 위해 인근 오염원이 없는 S-대학교와 산업단지 작업일과 비작업일 비교를 위해 주말시간대 산업단지 대기농 도도 동일한 방법으로 측정하였다. 이동측정시 안전상의 이유 로 기상측정장비를 설치하지 못하여 기온, 습도 등 기상자료 는 배제되었다.

\section{2. 조사항목 및 분석}

실시간 분석 대상 VOCs는 US EPA TO-15 method상의 독 성물질 64종과 악취물질 20종을 SIFT-MS를 통해 분석하였고, 입자상오염물질(PM-10, PM-2.5)은 $\mathrm{OPC}$ 를 통해 실시간 분석 하였다. 대기이동측정시스템으로 분석한 86종은 대기환경보 전법에서 정한 대기오염물질 64종 중 27종이 포함되어 있으 며, 유해성대기감시물질 43 종 중 21종, 휘발성유기화합물 지 정고시에서 정한 37 종 중 21 종, 악취방지법에서 정한 지정악 취물질 22종 중 20종, 화학물질관리법에서 지정한 사고대비 물질 97종 중 27종이 포함되어 있다. Table 1, 2에는 SIFT-MS 에서 분석한 VOCs와 악취물질 64종을 나타내었다.

Table 1의 16번, 24번, 63 번, Table 2의 5번, 9번, 14번, 15 번 물질은 SIFT-MS 분석시 동일한 프로덕트 이온을 형성하여 질량 스펙트럼이 동일하게 나타나 현재로는 분리가 되지 않는 다. 그러나 실시간 가스분석이라는 잇점을 가진 SIFT-MS는 $\mathrm{GC}$ 에서 주로 사용되는 컬럼을 이용한 물리적 분리 대신 낮은 에너지 준위를 가지는 이온소스를 이용하는 화학적 분리방식 으로, 반응가스(reaction gas) 없이 대기 중 산소와 질소, 수분 을 마이크로파에서 생성된 수많은 반응이온(reagent ion) 중 $\mathrm{H}_{3} \mathrm{O}^{+}, \mathrm{NO}^{+}, \mathrm{O}_{2}^{+}$을 선택적으로 flow tube에 흘려주어 반응이온 과 가스상 시료와 만나 화학적 특성에 따라 다양한 화학적 이온반응을 이용하여 프로덕트 이온을 생성한다. 생성된 프로 덕트 이온은 4중극 질량필터(quadrupole mass filter)에서 선택 적으로 분석하고자 하는 물질을 여과하여 검출기로 흘려주어 분석물의 절대농도를 다음 식으로 계산한다. 
Table 1. List of analyzed VOCs (US EPA TO-15 method).

\begin{tabular}{|c|c|c|c|c|c|}
\hline No & Compounds name & Molecule & No & Compounds name & Molecule \\
\hline 1 & Acetonitrile & $\mathrm{C}_{2} \mathrm{H}_{3} \mathrm{~N}$ & 32 & 1,4-dioxane & $\mathrm{C}_{4} \mathrm{H}_{8} \mathrm{O}_{2}$ \\
\hline 2 & Acetophenone & $\mathrm{C}_{8} \mathrm{H}_{8} \mathrm{O}$ & 33 & Epichlorohydrin & $\mathrm{C}_{3} \mathrm{H}_{5} \mathrm{ClO}$ \\
\hline 3 & Acrylamide & $\mathrm{C}_{3} \mathrm{H}_{5} \mathrm{NO}$ & 34 & 1,2-epoxybutane & $\mathrm{C}_{4} \mathrm{H}_{8} \mathrm{O}$ \\
\hline 4 & Acrylonitrile & $\mathrm{C}_{3} \mathrm{H}_{3} \mathrm{~N}$ & 35 & Ethylene Oxide & $\mathrm{C}_{2} \mathrm{H}_{4} \mathrm{O}$ \\
\hline 5 & Allyl Chloride & $\mathrm{C}_{3} \mathrm{H}_{5} \mathrm{Cl}$ & 36 & Hexachlorobutadiene & $\mathrm{C}_{4} \mathrm{Cl}_{6}$ \\
\hline 6 & Aniline & $\mathrm{C}_{6} \mathrm{H}_{7} \mathrm{~N}$ & 37 & Hexane & $\mathrm{C}_{6} \mathrm{H}_{14}$ \\
\hline 7 & Benzene & $\mathrm{C}_{6} \mathrm{H}_{6}$ & 38 & Isooctane & $\mathrm{C}_{8} \mathrm{H}_{18}$ \\
\hline 8 & Bromoform & $\mathrm{CHBr}_{3}$ & 39 & Isophorone & $\mathrm{C}_{9} \mathrm{H}_{14} \mathrm{O}$ \\
\hline 9 & 1,3-butadiene & $\mathrm{C}_{4} \mathrm{H}_{6}$ & 40 & Isopropyl Benzene & $\mathrm{C}_{9} \mathrm{H}_{12}$ \\
\hline 10 & Carbon Tetrachloride & $\mathrm{CCl}_{4}$ & 41 & Methanol & $\mathrm{CH}_{4} \mathrm{O}$ \\
\hline 11 & Carbonyl Sulfide & $\cos$ & 42 & 2-methylaziridine & $\mathrm{C}_{3} \mathrm{H}_{7} \mathrm{~N}$ \\
\hline 12 & Catechol & $\mathrm{C}_{6} \mathrm{H}_{6} \mathrm{O}_{2}$ & 43 & Methyl Bromide & $\mathrm{CH}_{3} \mathrm{Br}$ \\
\hline 13 & Chloroacetic Acid & $\mathrm{C}_{2} \mathrm{H}_{3} \mathrm{ClO}_{2}$ & 44 & Methyl Chloride & $\mathrm{CH}_{3} \mathrm{Cl}$ \\
\hline 14 & Chlorobenzene & $\mathrm{C}_{6} \mathrm{H}_{5} \mathrm{Cl}$ & 45 & Methylhydrazine & $\mathrm{CH}_{6} \mathrm{~N}_{2}$ \\
\hline 15 & 2-chloroethyl ether & $\mathrm{C}_{4} \mathrm{H}_{8} \mathrm{Cl}_{2} \mathrm{O}$ & 46 & Methyl lodide & $\mathrm{CH}_{3} \mathrm{I}$ \\
\hline \multirow{3}{*}{$16^{*}$} & Chloroform & $\mathrm{CHCl}_{3}$ & 47 & Methyl Isocyanate & $\mathrm{C}_{2} \mathrm{H}_{3} \mathrm{NO}$ \\
\hline & Methylen Chloride & $\mathrm{CH}_{2} \mathrm{Cl}_{2}$ & 48 & Methyl Methacrylate & $\mathrm{C}_{5} \mathrm{H}_{8} \mathrm{O}_{2}$ \\
\hline & 1,1,2,2-tetrachloroethane & $\mathrm{C}_{2} \mathrm{H}_{2} \mathrm{Cl}_{4}$ & 49 & Methyl Tert-Butyl Ether & $\mathrm{C}_{5} \mathrm{H}_{12} \mathrm{O}$ \\
\hline 17 & a-chlorotoluene & $\mathrm{C}_{7} \mathrm{H}_{7} \mathrm{Cl}$ & 50 & 2-nitropropane & $\mathrm{C}_{3} \mathrm{H}_{7} \mathrm{NO}_{2}$ \\
\hline 18 & o-cresol & $\mathrm{C}_{7} \mathrm{H}_{8} \mathrm{O}$ & 51 & $\mathrm{~N}$-nitrosomorpholine & $\mathrm{C}_{4} \mathrm{H}_{8} \mathrm{~N}_{2} \mathrm{O}_{2}$ \\
\hline 19 & 1,2-dibromo-3-chloropropane & $\mathrm{C}_{6} \mathrm{H}_{6} \mathrm{O}_{2}$ & 52 & Beta-Propiolactone & $\mathrm{C}_{3} \mathrm{H}_{4} \mathrm{O}_{2}$ \\
\hline 20 & 1,2-dibromoethane & $\mathrm{C}_{2} \mathrm{H}_{4} \mathrm{Br}_{2}$ & 53 & Styrene Oxide & $\mathrm{C}_{4} \mathrm{H}_{8} \mathrm{O}$ \\
\hline 21 & 1,4-dichlorobenzene & $\mathrm{C}_{6} \mathrm{H}_{4} \mathrm{Cl}_{2}$ & 54 & Tetrachloroethylene & $\mathrm{C}_{2} \mathrm{Cl}_{4}$ \\
\hline 22 & 1,1-dichloroethane & $\mathrm{C}_{2} \mathrm{H}_{4} \mathrm{Cl}_{2}$ & 55 & 1,2,4-trichlorobenzene & $\mathrm{C}_{6} \mathrm{H}_{3} \mathrm{Cl}_{3}$ \\
\hline 23 & 1,1-dichloroethene & $\mathrm{C}_{2} \mathrm{H}_{2} \mathrm{Cl}_{2}$ & 56 & 1,1,1-trichloroethane & $\mathrm{C}_{2} \mathrm{H}_{3} \mathrm{Cl}_{3}$ \\
\hline \multirow{2}{*}{$24 *$} & 1,2-dichloroethane & $\mathrm{C}_{2} \mathrm{H}_{4} \mathrm{Cl}_{2}$ & 57 & 1,1,2-trichloroethane & $\mathrm{C}_{2} \mathrm{H}_{3} \mathrm{Cl}_{3}$ \\
\hline & Vinyl Chloride & $\mathrm{C}_{2} \mathrm{H}_{3} \mathrm{Cl}$ & 58 & Trichloroethylene & $\mathrm{C}_{2} \mathrm{HCl}_{3}$ \\
\hline 25 & 1,2-dichloropropane & $\mathrm{C}_{3} \mathrm{H}_{6} \mathrm{Cl}_{2}$ & 59 & Triethylamine & $\mathrm{C}_{6} \mathrm{H}_{15} \mathrm{~N}$ \\
\hline 26 & (Z)-1,3-dichloropropene & $\mathrm{C}_{3} \mathrm{H}_{4} \mathrm{Cl}_{2}$ & 60 & Urethane & $\mathrm{C}_{3} \mathrm{H}_{7} \mathrm{NO}_{2}$ \\
\hline 27 & N,N-dimethylaniline & $\mathrm{C}_{8} \mathrm{H}_{11} \mathrm{~N}$ & 61 & Vinyl Acetate & $\mathrm{C}_{4} \mathrm{H}_{6} \mathrm{O}_{2}$ \\
\hline 28 & Dimethylcarbamoyl Chloride & $\mathrm{C}_{3} \mathrm{H}_{6} \mathrm{CINO}$ & 62 & Acrolein & $\mathrm{C}_{3} \mathrm{H}_{4} \mathrm{O}$ \\
\hline 29 & N,N-dimethylformamide & $\mathrm{C}_{3} \mathrm{H}_{7} \mathrm{NO}$ & \multirow{2}{*}{$63^{*}$} & Ethyl Chloride & $\mathrm{C}_{2} \mathrm{H}_{5} \mathrm{Cl}$ \\
\hline 30 & Dimethylnitrosamine & $\mathrm{C}_{2} \mathrm{H}_{6} \mathrm{~N}_{2} \mathrm{O}$ & & Phosgene & $\mathrm{CCl}_{2} \mathrm{O}$ \\
\hline 31 & Dimethyl Sulfate & $\mathrm{C}_{2} \mathrm{H}_{6} \mathrm{O}_{4} \mathrm{~S}$ & 64 & Formaldehyde & $\mathrm{CH}_{2} \mathrm{O}$ \\
\hline
\end{tabular}

* They are not separated in SIFT-MS and are marked together.

Table 2. List of analyzed odorous compounds.

\begin{tabular}{|c|c|c|c|c|c|}
\hline No & Compounds name & Molecule & No & Compounds name & Molecule \\
\hline 1 & Ammonia & $\mathrm{NH}_{3}$ & 11 & Pentanal & $\mathrm{C}_{5} \mathrm{H}_{10} \mathrm{O}$ \\
\hline 2 & Methyl Mercaptan & $\mathrm{CH}_{4} \mathrm{~S}$ & 12 & 3-methylbutanoic acid & $\mathrm{C}_{5} \mathrm{H}_{10} \mathrm{O}$ \\
\hline 3 & Hydrogen Sulfide & $\mathrm{H}_{2} \mathrm{~S}$ & 13 & Toluene & $\mathrm{C}_{7} \mathrm{H}_{8}$ \\
\hline 4 & Dimethyl Sulfide & $\mathrm{C}_{2} \mathrm{H}_{6} \mathrm{~S}$ & \multirow{2}{*}{$14^{* *}$} & Xylenes & $\mathrm{C}_{8} \mathrm{H}_{10}$ \\
\hline \multirow{2}{*}{$5^{* *}$} & Phenol $^{*}$ & $\mathrm{C}_{6} \mathrm{H}_{5} \mathrm{OH}$ & & Ethylbenzene & $\mathrm{C}_{8} \mathrm{H}_{10}$ \\
\hline & Dimethyl Disulfide & $\mathrm{C}_{2} \mathrm{H}_{6} \mathrm{~S}_{2}$ & \multirow{2}{*}{$15^{\star \star}$} & Methyl Ethyl Ketone & $\mathrm{C}_{4} \mathrm{H}_{8} \mathrm{O}$ \\
\hline 6 & Trimethylamine & $\mathrm{C}_{3} \mathrm{H}_{9} \mathrm{~N}$ & & Acrylic Acid* & $\mathrm{C}_{3} \mathrm{H}_{4} \mathrm{O}_{2}$ \\
\hline 7 & Acetaldehyde & $\mathrm{C}_{2} \mathrm{H}_{4} \mathrm{O}$ & 16 & Methyl Isobutyl Ketone & $\mathrm{C}_{6} \mathrm{H}_{12} \mathrm{O}$ \\
\hline 8 & Styrene & $\mathrm{C}_{8} \mathrm{H}_{8}$ & 17 & Butyl Acetate & $\mathrm{C}_{6} \mathrm{H}_{12} \mathrm{O}_{2}$ \\
\hline \multirow{2}{*}{$9^{* \star}$} & Propionaldehyde & $\mathrm{C}_{3} \mathrm{H}_{6} \mathrm{O}$ & 18 & Propanoic Acid & $\mathrm{C}_{3} \mathrm{H}_{6} \mathrm{O}_{2}$ \\
\hline & Propylene Oxidel $^{*}$ & $\mathrm{C}_{3} \mathrm{H}_{6} \mathrm{O}$ & 19 & Butanoic Acid & $\mathrm{C}_{4} \mathrm{H}_{8} \mathrm{O}_{2}$ \\
\hline 10 & Butanal & $\mathrm{C}_{4} \mathrm{H}_{8} \mathrm{O}$ & 20 & Isobutyl Alcohol & $\mathrm{C}_{4} \mathrm{H}_{10} \mathrm{O}$ \\
\hline
\end{tabular}

* Phenol, propylene oxidel and acrylic acid are not odorous compounds. But they are not separated in SIFT-MS.

${ }^{* *}$ They are not separated in SIFT-MS and are marked together. 
Table 3. Operating condition of SIFT-MS for VOCs and odorous compounds analysis.

\begin{tabular}{cc} 
Parameter & Value \\
Sample plate temperature & $120^{\circ} \mathrm{C}$ \\
\hline Flow tube temperature & $120^{\circ} \mathrm{C}$ \\
\hline Hex heater temperature & $120^{\circ} \mathrm{C}$ \\
\hline Wet source pressure & $850 \mathrm{mTorr}$ \\
\hline Dry source pressure & $3.50 \mathrm{Torr}$ \\
\hline Flow tube pressure & $110 \mathrm{mTorr}$ \\
\hline Upstream pressure & $2.5 \mathrm{e}^{-0.4} \mathrm{Torr}$ \\
\hline Downstream pressure & $50 \mathrm{mTorr}$ \\
\hline
\end{tabular}

$$
[A]=y \frac{\left[P^{+}\right]}{\left[R^{+}\right] k}
$$

여기서, $[\mathrm{A}]$ : 농도(ppbv)

$$
\begin{aligned}
y & : \text { 기기보정계수(Instrument Caibration } \\
& \text { Function; ICF) } \\
& {\left[\mathrm{P}^{+}\right]: \text {생성이온량 } } \\
& {\left[\mathrm{R}^{+}\right]: \text {반응이온량 } }
\end{aligned}
$$$$
k \text { : 반응 속도 상수 }
$$

시료의 농축 및 전처리 필요없이 분석이 가능하며, 분석 전 에 검증(validation) 과정을 통해 장비성능을 일정하게 유지시 켜주어, GC-MS에서 사용되는 상대정량법과 달리 표준물질 없이도 분석대상화합물의 절대정량이 가능하다. SIFT-MS의 분석조건을 Table 3에 나타내었다.

광학입자계수기(OPC)는 로렌츠-미 산란을 이용하여 입자 의 측방 산란광을 전기신호로 바꾸어 입자의 크기를 측정하 고, 전기신호의 빈도를 분석하여 16 개 입경별 입자의 계수를 측정한다. ${ }^{10)}$ 여기에 측정된 입자의 밀도를 곱하여 PM-10. PM-2.5 질량농도를 20초 단위로 산출하였다.

\section{3. 결과 및 고찰}

\section{1. 산업단지별 대기오염물질 농도}

SIFT-MS와 OPS를 탑재한 대기이동측정시스템을 이용하여 사상공업지역과 신평·장림일반산업단지 주변 대기오염물질 을 공장작업일과 비작업일로 구분하여 측정하였고, 오염원이 없는 주변 배경농도와의 비교를 위해 S-대학교 대기농도도 동 일한 방법으로 측정한 평균농도를 Table4에 나타내었다. 측 정일은 계절적 변화를 비교하기 위해 2019년 5월(봄), 8월(여 름), 10 월(가을)에 조사하였다.

SIFT-MS 분석항목 중 대기환경기준 물질인 벤젠은 배경지 역과 조사지점 모두 대기환경기준 $5 \mu \mathrm{g} / \mathrm{m}^{3}(1.54 \mathrm{ppb})$ 이내로 나타났으며, 사상공업지역은 신평·장림일반산업단지보다 많 은 항목이 상대적으로 높은 농도값을 나타내었다. 특히, 사상

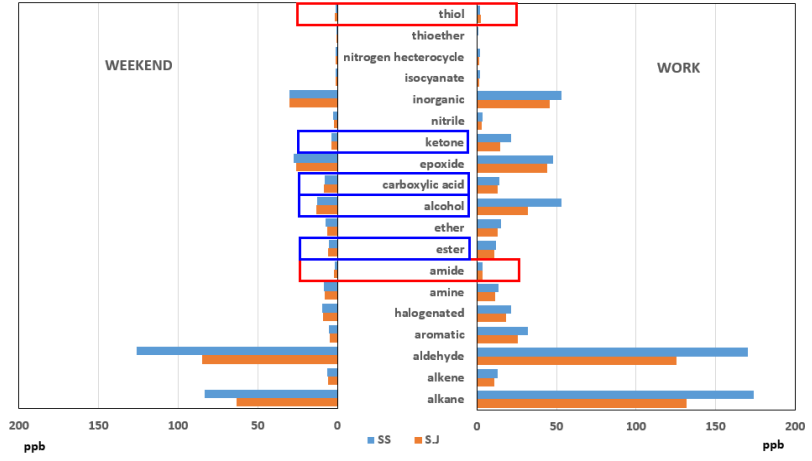

Fig. 2. Plots of chemical group concentration in industrial complexes.

공업지역의 경우 헥산, 메탄올, 벤젠, 톨루엔, 자일렌+에틸벤 젠 등 방향족화합물의 농도가 높게 나타났으며, 신평·장림일 반산업단지는 메틸클로라이드, 메틸히드라진, 2-나이트로프 로페인 등의 농도가 높게 나타났다. 공장작업이 없는 산업단 지별 주말농도는 배경농도수준으로 낮아져서 산업단지 내 대 기오염물질의 농도는 입주업종의 작업유무에 따라 높아지는 것을 알 수 있다. 그러나, 사상공업지역과 신평·장림일반산업 단지의 경우 헥산이 가장 높은 농도로 나타나므로, 중요관리 대상물질로 VOCs 중 헥산을 우선적으로 고려해야 할 것으로 보여진다.

$\mathrm{OPC}$ 측정값인 미세먼지(PM-2.5, PM-10)는 대기정체, 국외 유입 등 기상조건에 따라 달라지므로, 동일한 시간대에 측정 하지 않아 산업단지별 비교가 어려우나, 조사기간 동안 미세 먼지 평균값은 공장작업일은 ‘보통', 비작업일은 ‘좋음'으로 조사되었다.

Fig. 2에는 화학물질군에 따른 농도를 비교하기 위하여 각 화학물질군 농도를 합산하여 산업단지별로 나타내었다. 대부 분의 화학물질군이 사상공업지역에서 높게 나타났으며, 알칸, 알데하이드, 알콜계열의 화학물질이 상대적으로 높게 조사되 었다. 신평·장림일반산업공단의 경우 아미드, 티올계열의 화 학물질이 상대적으로 높게 조사되었으며, 공장작업이 중단되 는 주말의 경우 공장작업기간과는 다르게 에스터, 알콜, 카르 복실산, 케톤계열의 화확물질군이 신평·장림일반산업단지에 서 상대적으로 높게 나타났다.

\section{2. 사상공업지역 유해물질 분포}

대기환경보전법에는 총 64 종의 물질을 대기오염물질로 지 정하여 관리하고 있으며, 이들 중에 사람의 건강이나 동식물 의 생육에 위해를 끼칠 수 있어 지속적인 측정이나 감시·관찰 등이 필요하다고 인정되는 43종의 물질을 유해성대기감시물 질로 지정하고, 유해성대기감시물질 중 저농도에서도 장기적 인 섭취나 노출에 의해 사람의 건강이나 동식물의 생육에 직 접 또는 간접으로 위해를 끼칠 수 있는 35 종을 특정대기유해 물질로 지정하여 대기배출에 대한 관리를 하고 있다. 이 물질 
Table 4. Concentration of VOCs, odorous compounds, PM-2.5 and PM-10 in industrial complexes.

\begin{tabular}{|c|c|c|c|c|c|c|}
\hline \multirow{2}{*}{ Group } & \multirow{2}{*}{ Compounds (ppb) } & \multicolumn{2}{|c|}{ Sasang } & \multicolumn{2}{|c|}{ Shinpyeong-Jangrim } & \multirow{2}{*}{$\begin{array}{l}\text { Silla-Universit) } \\
\text { (background) }\end{array}$} \\
\hline & & Work & Weekend & Work & Weekend & \\
\hline \multirow{14}{*}{ Alkane } & Methyl chloride & 1.89 & 0.66 & 2.35 & 0.72 & 0.55 \\
\hline & Methyl bromide & 12.24 & 6.36 & 11.01 & 6.38 & 1.17 \\
\hline & Ethyl chloride+phosgene & 7.44 & 3.22 & 5.16 & 2.22 & 0.93 \\
\hline & Methyl iodide & 13.87 & 9.76 & 10.85 & 7.81 & 4.15 \\
\hline & 1.1-dichloroethane & 6.82 & 3.26 & 5.47 & 2.37 & 0.85 \\
\hline & $\begin{array}{l}\text { Chloroform+methylen } \\
\text { chloride+1.1.2.2-tetrachloroethane }\end{array}$ & 13.39 & 6.28 & 9.34 & 5.95 & 2.03 \\
\hline & Hexane & 102.55 & 46.05 & 74.10 & 30.19 & 10.34 \\
\hline & 1.1.1-trichloroethane & 2.99 & 1.32 & 2.50 & 1.59 & 0.34 \\
\hline & Carbon tetrachloride & 2.13 & 0.95 & 1.76 & 0.78 & 0.2 \\
\hline & 1.2-dichloroethane+vinyl chloride & 3.04 & 1.38 & 2.33 & 1.04 & 0.57 \\
\hline & Isooctane & 4.76 & 2.66 & 3.83 & 2.80 & 1.07 \\
\hline & 1.2-dibromoethane & 1.60 & 0.85 & 1.48 & 0.83 & 0.19 \\
\hline & 2-nitropropane & 0.72 & 0.39 & 1.00 & 0.39 & 0.12 \\
\hline & 1.2-dibromo-3-chloropropane & 0.31 & 0.13 & 0.32 & 0.08 & 0.01 \\
\hline \multirow{6}{*}{ Alkene } & 1.3-butadiene & 0.22 & 0.16 & 0.15 & 0.10 & 0.06 \\
\hline & 1.1-dichloroethene & 7.96 & 3.86 & 6.53 & 3.70 & 1.08 \\
\hline & Allyl chloride & 1.36 & 0.76 & 1.14 & 0.73 & 0.52 \\
\hline & (Z)-1.3-dichloropropene & 1.90 & 0.75 & 1.71 & 0.66 & 0.19 \\
\hline & Tichloroethylene & 1.07 & 0.45 & 0.84 & 0.42 & 0.26 \\
\hline & Tetrachloroethylene & 0.53 & 0.23 & 0.61 & 0.21 & 0 \\
\hline \multirow{5}{*}{ Aldehyde } & Formaldehyde & 36.18 & 21.14 & 35.21 & 23.20 & 12.63 \\
\hline & Acetaldehyde & 14.76 & 9.89 & 14.92 & 10.52 & 2.17 \\
\hline & Propionaldehyde+propylene oxidel & 7.87 & 2.79 & 5.43 & 2.31 & 0.89 \\
\hline & Butanal & 3.01 & 1.80 & 2.52 & 1.72 & 0.43 \\
\hline & Pentanal & 2.25 & 1.02 & 1.61 & 1.11 & 0.34 \\
\hline \multirow{6}{*}{ Aromatic } & Benzene & 0.42 & 0.17 & 0.32 & 0.18 & 0.14 \\
\hline & Toluene & 11.70 & 1.43 & 6.29 & 0.99 & 0.61 \\
\hline & Xylenes + ethylbenzene & 8.12 & 1.10 & 6.77 & 1.05 & 0.4 \\
\hline & Styrene & 0.79 & 0.33 & 0.67 & 0.33 & 0.15 \\
\hline & Isopropyl benzene & 8.02 & 1.49 & 8.67 & 1.47 & 0.35 \\
\hline & Styrene oxide & 2.84 & 0.95 & 2.97 & 0.91 & 0.15 \\
\hline \multirow{8}{*}{ Halogenated } & 1.2-dichloropropane & 6.95 & 3.08 & 6.25 & 2.70 & 0.47 \\
\hline & 1.1.2-trichloroethane & 8.18 & 3.62 & 6.94 & 3.66 & 0.98 \\
\hline & Chlorobenzene & 2.56 & 1.63 & 2.10 & 1.51 & 0.48 \\
\hline & Bromoform & 0.13 & 0.04 & 0.16 & 0.05 & 0.01 \\
\hline & 1-chlorotoluene & 3.09 & 1.11 & 2.59 & 0.88 & 0.23 \\
\hline & 1.4-dichlorobenzene & 0.17 & 0.05 & 0.18 & 0.05 & 0.01 \\
\hline & Hexachlorobutadiene & 0.08 & 0.01 & 0.03 & 0.00 & 0 \\
\hline & 1.2.4-trichlorobenzene & 0.25 & 0.08 & 0.20 & 0.05 & 0 \\
\hline \multirow{8}{*}{ Amine } & 2-methylaziridine & 1.33 & 0.81 & 1.17 & 0.70 & 0.13 \\
\hline & Triethylamine & 1.04 & 0.70 & 0.97 & 0.72 & 0.15 \\
\hline & Methylhydrazine & 3.12 & 3.40 & 4.00 & 3.26 & 3.51 \\
\hline & Dimethylnitrosoamine & 0.87 & 0.70 & 0.74 & 0.59 & 0.1 \\
\hline & Aniline & 0.96 & 0.28 & 0.68 & 0.26 & 0.08 \\
\hline & Acrylamide & 1.50 & 0.92 & 1.31 & 0.92 & 0.17 \\
\hline & N.N-dimethylaniline & 0.78 & 0.15 & 0.68 & 0.16 & 0.03 \\
\hline & Trimethylamine & 3.88 & 1.28 & 2.94 & 1.57 & 0.29 \\
\hline
\end{tabular}


Table 4. To be Continued.

\begin{tabular}{|c|c|c|c|c|c|c|}
\hline \multirow{2}{*}{ Group } & \multirow{2}{*}{ Compounds (ppb) } & \multicolumn{2}{|c|}{ Sasang } & \multicolumn{2}{|c|}{ Shinpyeong-Jangrim } & \multirow{2}{*}{$\begin{array}{l}\text { Silla-Universit) } \\
\text { (background) }\end{array}$} \\
\hline & & Work & Weekend & Work & Weekend & \\
\hline \multirow{2}{*}{ Amide } & N.N-dimethylformamide & 2.54 & 1.22 & 2.45 & 1.44 & 0.45 \\
\hline & Urethane & 0.93 & 0.58 & 1.19 & 0.54 & 0.15 \\
\hline \multirow{5}{*}{ Ester } & Vinyl acetate & 3.16 & 1.93 & 3.15 & 2.24 & 0.57 \\
\hline & Methyl methacrylate & 1.21 & 0.70 & 1.07 & 0.65 & 0.16 \\
\hline & Beta-propiolactone & 3.03 & 1.25 & 2.65 & 1.21 & 0.57 \\
\hline & Dimethyl sulfate & 1.11 & 0.61 & 0.99 & 0.59 & 0.14 \\
\hline & Butyl acetate & 3.74 & 0.89 & 3.23 & 1.02 & 0.39 \\
\hline \multirow{3}{*}{ Ether } & Methyl tert-butyl ether & 6.78 & 3.10 & 5.86 & 2.53 & 0.87 \\
\hline & 1.4-dioxane & 3.71 & 2.19 & 3.14 & 2.09 & 0.51 \\
\hline & 2-chloroethyl ether & 4.48 & 1.91 & 4.08 & 1.62 & 0.39 \\
\hline \multirow{5}{*}{ Alcohol } & Methanol & 41.45 & 7.69 & 22.09 & 8.23 & 2.69 \\
\hline & o-cresol & 0.35 & 0.16 & 0.29 & 0.16 & 0.06 \\
\hline & Catechol & 0.36 & 0.22 & 0.29 & 0.21 & 0.07 \\
\hline & Phenol+dimethyl disulfide & 0.94 & 0.48 & 0.91 & 0.54 & 0.07 \\
\hline & Isobutyl alcohol & 10.29 & 4.43 & 8.68 & 4.13 & 1.48 \\
\hline \multirow{5}{*}{$\begin{array}{l}\text { Carboxylic } \\
\text { acid }\end{array}$} & Dimethylcarbamoyl chloride & 1.97 & 1.12 & 1.73 & 1.11 & 0.23 \\
\hline & Chloroacetic acid & 1.23 & 0.69 & 1.20 & 0.86 & 0.15 \\
\hline & 3-methylbutanoic acid & 4.23 & 2.64 & 3.65 & 2.81 & 0.61 \\
\hline & Butanoic acid & 3.17 & 1.44 & 3.56 & 1.26 & 0.76 \\
\hline & Propanoic acid & 3.44 & 2.00 & 3.05 & 2.29 & 0.54 \\
\hline \multirow{3}{*}{ Epoxide } & Ethylene oxide & 17.38 & 12.85 & 17.03 & 12.60 & 2.55 \\
\hline & 1.2-epoxybutane & 5.79 & 3.43 & 4.82 & 3.25 & 0.72 \\
\hline & Epichlorohydrin & 24.84 & 11.13 & 22.15 & 10.08 & 4.32 \\
\hline \multirow{4}{*}{ Ketone } & Methyl ethyl ketone+acrylic acid & 13.45 & 1.80 & 8.82 & 1.83 & 0.7 \\
\hline & Methyl isobutyl ketone & 3.32 & 0.94 & 2.01 & 1.04 & 0.25 \\
\hline & Acetophenone & 4.35 & 0.60 & 3.35 & 0.72 & 0.13 \\
\hline & Isophorone & 0.35 & 0.19 & 0.30 & 0.17 & 0.05 \\
\hline \multirow{2}{*}{ Nitrile } & Acrylonitrile & 1.31 & 1.12 & 1.20 & 0.83 & 0.11 \\
\hline & Acetonitrile & 2.04 & 1.35 & 2.04 & 1.50 & 0.29 \\
\hline \multirow{3}{*}{ Inorganic } & Carbonyl sulfide & 14.35 & 8.02 & 13.98 & 7.96 & 2.81 \\
\hline & Ammonia & 36.64 & 20.80 & 30.33 & 20.08 & 27.36 \\
\hline & Hydrogen sulfide & 1.93 & 1.54 & 1.71 & 2.23 & 0.74 \\
\hline Isocyanate & Methyl isocyanate & 1.81 & 1.13 & 1.59 & 1.07 & 0.22 \\
\hline $\begin{array}{c}\text { Nitrogen } \\
\text { hecterocycle }\end{array}$ & $\mathrm{N}$-nitrosomorpholine & 1.79 & 1.36 & 1.55 & 1.33 & 0.33 \\
\hline Thioether & Dimethyl sulfide & 0.87 & 0.22 & 0.46 & 0.17 & 0.09 \\
\hline Thiol & Methyl mercaptan & 2.23 & 0.97 & 2.76 & 1.74 & 0.34 \\
\hline \multirow{2}{*}{ Particle } & PM-2.5 (ug/m³) & 26.86 & 6.71 & 15.10 & 5.72 & 5.75 \\
\hline & $\mathrm{PM}-10\left(\mathrm{ug} / \mathrm{m}^{3}\right)$ & 60.56 & 14.38 & 52.98 & 20.35 & 15.55 \\
\hline
\end{tabular}

들은 VOCs와 지정악취물질, 발암 및 발암우려물질 등이 포함 된다.

본 연구에서는 SIFT-MS를 탑재한 대기이동측정시스템을 이용하여 US EPA TO-15 method상의 VOCs 64종과 악취물질 20 종을 측정·분석하였고, 이 중 사상공업지역에서 고농도로 나타난 헥산, 메탄올 등과 VOCs인 벤젠, 톨루엔, 자일렌+에 틸벤젠, 스타이렌, 포름알데하이드, 아세트알데하이드, 그리
고 대기오염물질 배출허용기준이 있는 암모니아, 황화수소, 염화비닐, 트리클로로에틸렌, 1.3-부타디엔의 농도변화를 Fig. 3 에 나타내었다,

연구기간동안 사상공업지역의 헥산은 평균 $102.55 \mathrm{ppb}$ 로 배경농도 평균 $10.34 \mathrm{ppb}$ 보다 매우 높게 나타났으며, SIFT-MS 분석항목 중 가장 높은 농도로 조사되었다. 헥산은 용기용매, 접착제 등 제조사업장과 식품용 오일 추출에 사용 


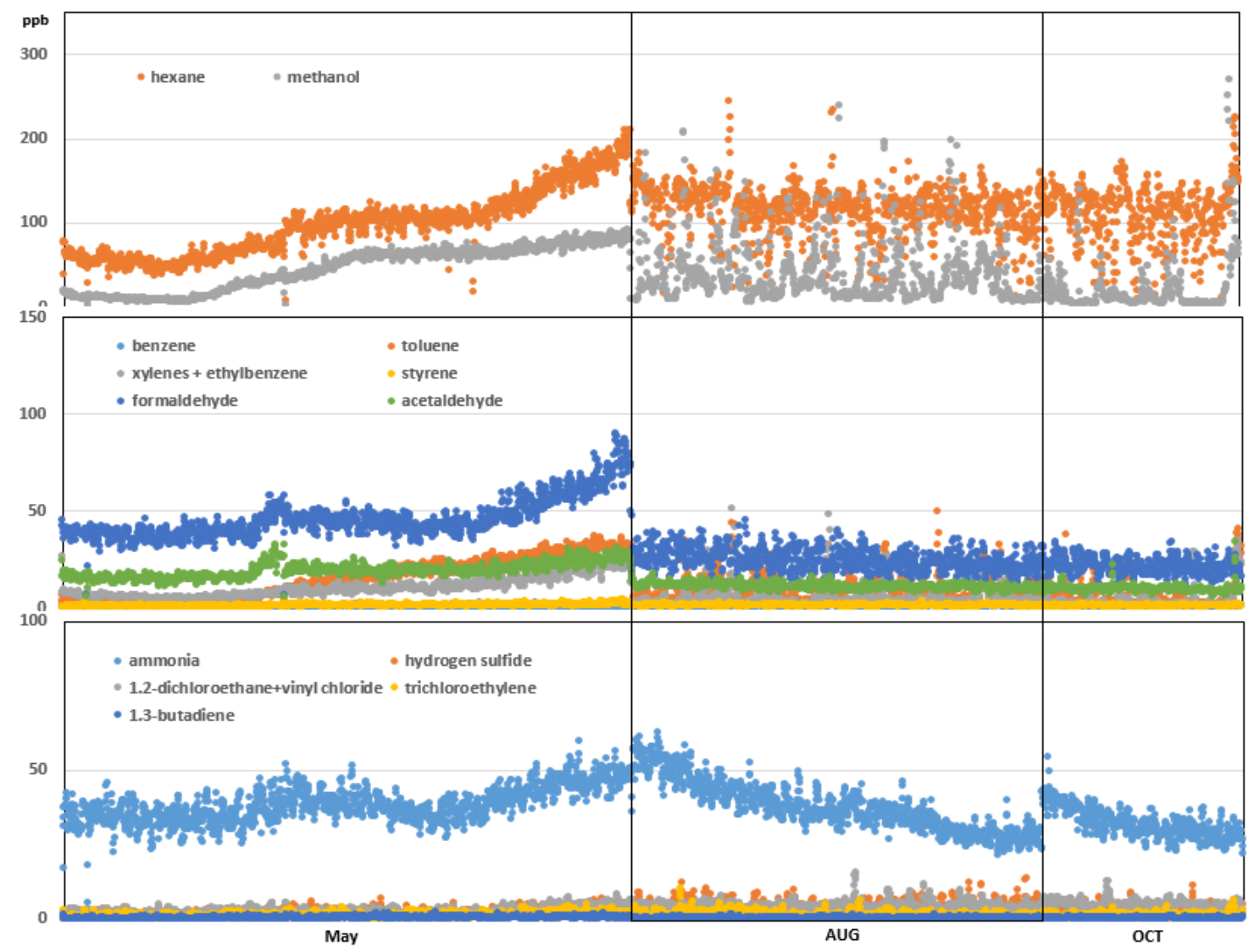

Fig. 3. Variations of hazardous air pollutant concentration in Sasang industrial area.

되며, 가솔린이나 등유 등에 포함되어 있으며 특정대기오염 물질로 분류되어 있지는 않지만 신경독성을 가지는 생식독 소 물질이므로 중점관리가 필요할 것이다. ${ }^{11)}$ 헥산은 노동부 TWA $50 \mathrm{ppm}$ 으로 산업안전보건법에 의해 관리되어진다. 사 상공업단지 메탄올도 평균농도 $41.45 \mathrm{ppb}$ 로 배경농도 평균 $2.69 \mathrm{ppb}$ 보다 매우 높게 나타났다. 메탄올은 전기, 전자, 금속 공업, 석유화학, 식품공업, 폐수처리 등 사업장이 주 발생원이 며, 노동부 TWA $200 \mathrm{ppm}, \mathrm{AEGL}-1670 \mathrm{ppm}$ 으로 관리된다.

Fig.3은 사상공업지역의 도로를 이동하면서 대기오염물질 을 20 초 간격으로 측정한 결과이므로, 계절적인 영향보다는 이동측정 시 주변 배출원으로부터 배출되는 오염원의 영향이 크기 때문에 사상공업지역의 계절적 농도변화를 판단하기에 는 부족하나, $\mathrm{VOCs}$ 의 경우 5 월이 가장 높았으며, 8 월, 10 월 순으로 농도감소가 일어나는 것을 알 수 있다, Cheng 등의 연구에서 방향족 탄화수소의 계절적 변화 중 봄철 농도가 가 장 높은 것으로 나타났으며, Ahn 등 국내 여러 연구에서 $\mathrm{VOCs}$ 의 농도가 봄, 겨울, 여름, 가을 순으로 저하되는 결과와 유사한 결과임을 알 수 있다. ${ }^{12-14)}$ 초봄과 겨울철의 경우 난방 연료연소와 대기역전현상이 VOCs의 농도를 상승시키는 원 인으로 알려져 있다. ${ }^{15)}$ 반면, 일부 악취물질은 여름철에 비교 적 농도가 높게 나타났다. 헥산과 메탄올의 경우 8 월과 10 월 측정값의 변화폭이 증가하였는데, 이는 이동측정 특성에 따른
산업단지 내 교통정체 영향으로 순간풍속 및 오염원과의 이격 거리에 의한 것으로 판단된다.

따라서, 사상공업지역내 오염배출원 위치를 파악하기 위해 SIFT-MS로 측정한 유해대기오염물질 농도를 지리정보시스 템(GPS) 자료와 연계하여 오염지도를 Fig.4에 나타내었으며, 배출원에 따라 낙동대로와 감전천 주변의 오염도가 상대적으 로 높게 나타남을 알 수 있다. 미세먼지(PM-2.5, PM-10)의 경우, 배출원에 의한 오염보다는 특정구간에서 차량 등에 의 해 농도 급상승하는 구간이 나타났다. 대기 중 PM-2.5 농도는 직접배출에 의한 영향보다는 $\mathrm{NOx}, \mathrm{SOx}, \mathrm{NH}_{3}, \mathrm{VOCs}$ 등이 대 기 중 산화되는 2 차 생성이 중요하다. 한국환경정책평가연구 원 “지자체별 오염원별·물질별 미세먼지 기여도 전환율 산 정” 보고서에 의하면 $\mathrm{NH}_{3}$ 의 미세먼지 기여도가 가장 높게 나 타났으며, 전국 17 개 지자체별, 오염원별(점, 선, 면), 배출물 질별 기여도와 전환율을 발표하였고, 부산의 경우 $\mathrm{NOx}$ $0.06 \%$, $\mathrm{SOx} 0.70 \%, \mathrm{NH}_{3} 5.51 \%$, VOCs $0.06 \%$ 의 PM- 2.5 기여 율로 나타났다. ${ }^{16)}$ 따라서, 본 연구에서는 SIFT-MS로 분석한 VOCs 물질 농도분포와 PM-2.5 농도분포와의 상관관계도 비 교해보았다.

GPS 좌표와 연계한 PM-2.5 농도분포 상관관계는 VOCs 물질별 농도분포와 낮은 상관관계로 나타났고, $\mathrm{NH}_{3}$ 도 $\mathrm{R}=0.0319667003$ 으로 상관관계는 낮았으며, 아이소프로필벤 


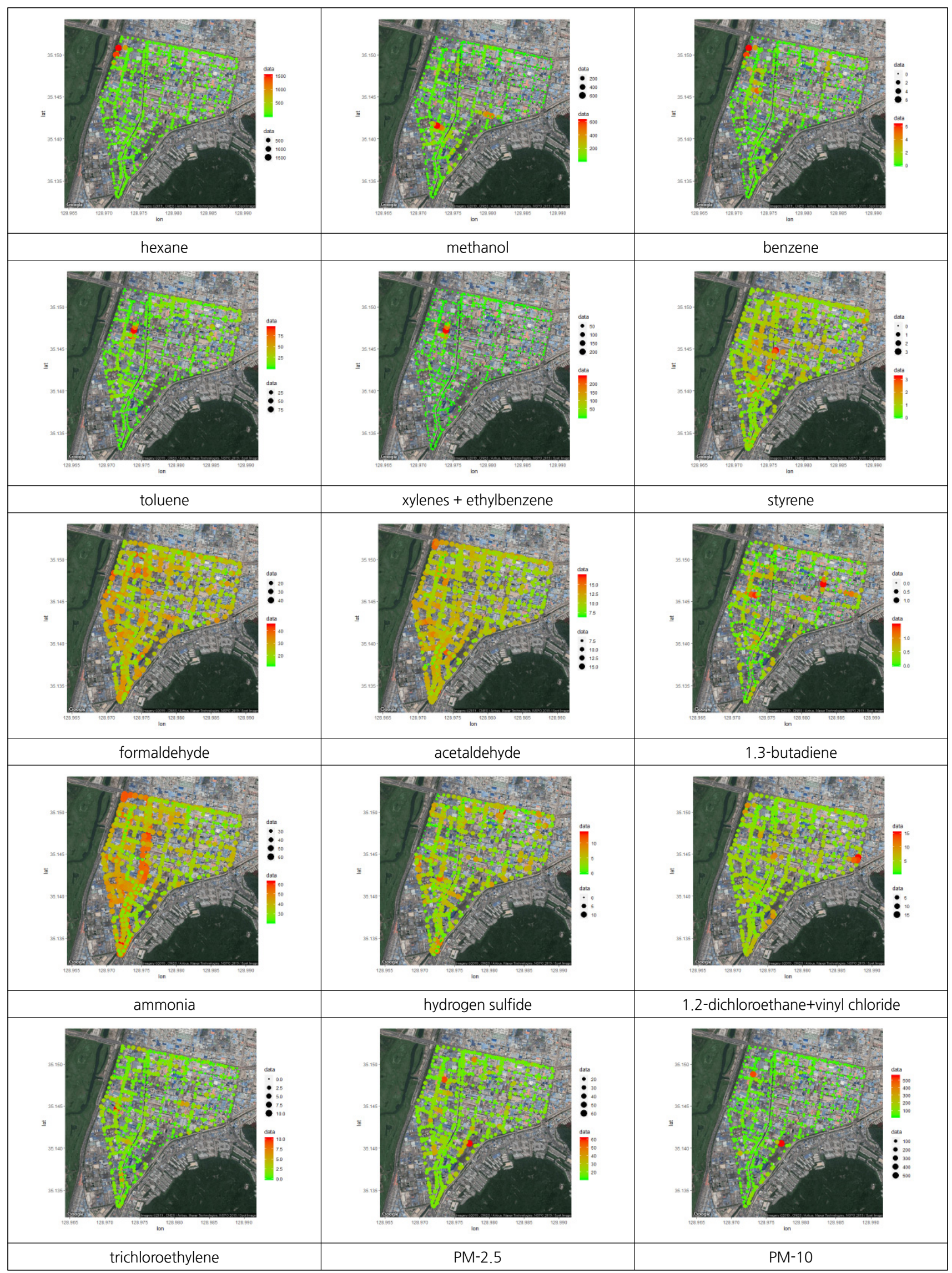

Fig. 4. Map of hazardous air pollutant concentration in Sasang industrial area. 


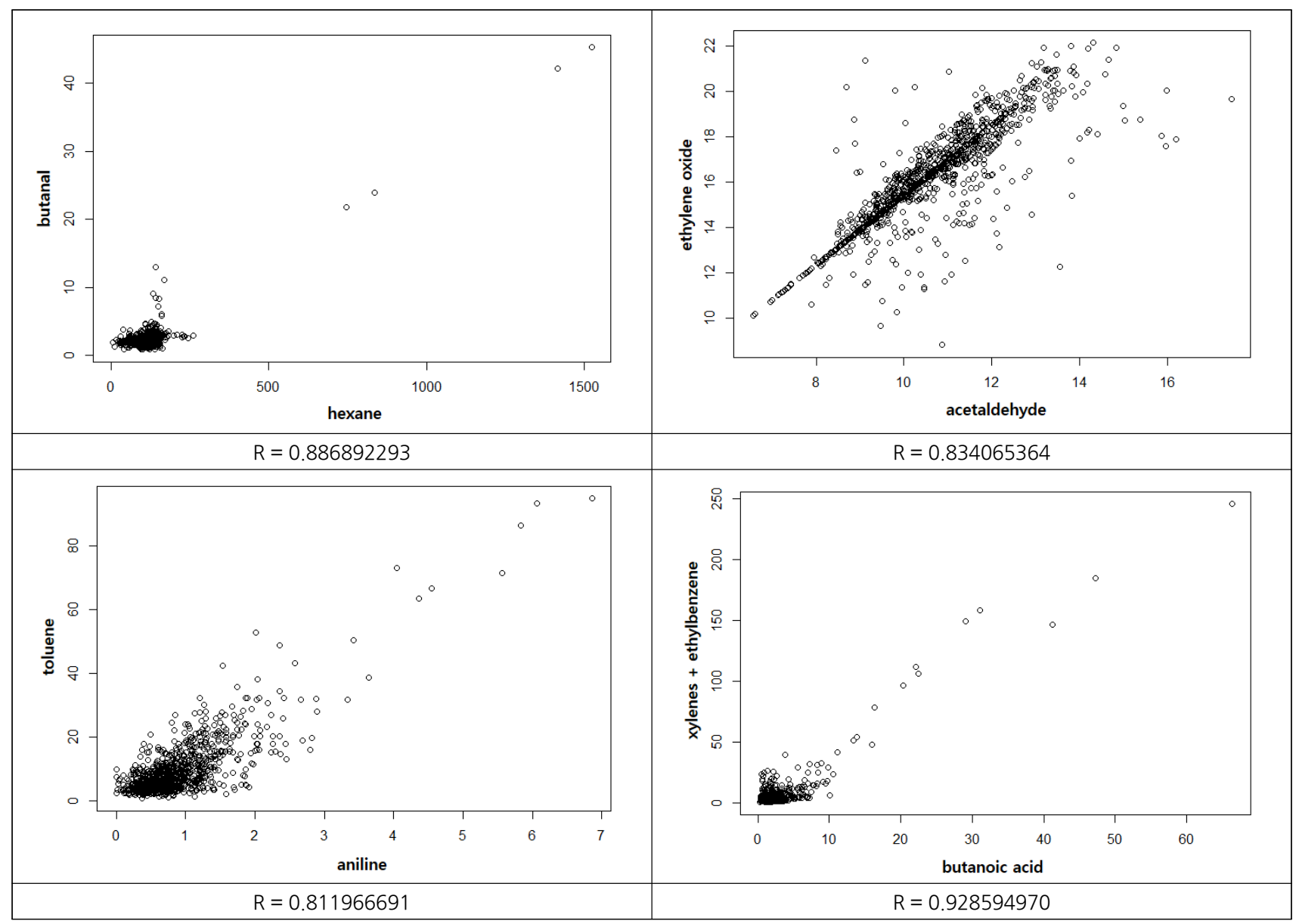

Fig. 5. Scatter plot of hazardous air pollutants in Sasang industrial area.

젠이 86 종 중 $\mathrm{R}=0.32452359$ 로 가장 높은 값으로 평가되었다, 본 연구는 고정지점에 의한 측정이 아니라 차량을 이용한 이 동측정값이므로 배출원에서 발생된 VOCs 및 $\mathrm{NH}_{3}$ 가 직접적 으로 PM-2.5로 2차 생성되는 값을 측정하지 못하였고, 이동차 량에 탑재된 $\mathrm{OPC}$ 측정값은 도로를 이동하는 차량에 의한 재 비산먼지의 값이 측정된 결과로 판단된다.

Fig.5는 SIFT-MS 분석물질 86 종, OPC 분석물질 2종의 농 도분포 상관관계를 조사하여 $80 \%$ 이상의 상관도를 보이는 물 질을 그래프로 나타내었다.

사상공업지역내 가장 높은 농도로 조사된 헥산은 뷰틸알데 하이드(butanal) 농도분포와 유사하게 나타났다. 뷰틸알데하 이드는 생산공정이나 자동차와 같은 1 차 배출원에서 상당량 이 배출되므로, Fig.4의 헥산 농도분포와 같이 사상공업지역 도로변과 자동차매매단지 및 주유소 부근에서 높게 나타났다. 휘발성이 강한 아세트알데하이드는 에틸렌옥사이드와 함께 유기공업 제품원료를 사용하는 공장부근에서 높게 나타났다. VOCs 중 환경보건학적 중요성이 큰 BTEX 그룹의 경우 분포 상관도가 높게 나타났으며, 벤젠의 수소 하나가 아민기로 치 환된 아닐린의 경우도 톨루엔과 유사한 농도분포를 보이는 것으로 조사되었다. 그 외 SIFT-MS 분석물질 중 메틸-t 뷰틸
에테르와 프로피온알데하이드+프로필렌옥사이드는 $98.9 \%$, 1.1-디클로에텐과 1.1.2-트리클로에텐은 95.2\%, 우레탄과 2나이트로프로페인은 $87.2 \%$, 메틸아이소시네이트와 2-메틸아 지리딘은 $86 \%$ 정도 상관관계를 보였다.

\section{3. 신평· 장림일반산업단지 유해물질 분포}

사상공업지역에서의 연구과 동일하게 SIFT-MS로 측정하였 고, 이중 신평·장림일반산업단지에서 고농도로 나타난 메틸 클로라이드, 메틸히드라진, 2-나이트로프로페인 등과 VOCs 인 벤젠, 톨루엔, 자일렌+에틸벤젠, 스타이렌, 포름알데하이 드, 아세트알데하이드, 그리고 대기오염물질 배출허용기준이 있는 암모니아, 황화수소, 염화비닐, 트리클로로에틸렌, 1.3부타디엔에 대한 농도변화를 Fig.6에 나타내었다,

연구기간동안 사상공업지역보다 높게 나타난 물질은 메틸 클로라이드, 메틸히드라진, 2-나이트로프로페인이며, 메틸클

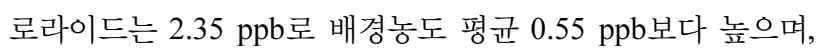
사상공업지역 평균 $1.89 \mathrm{ppb}$ 보다 높게 나타났다. 메틸클로라 이드는 냉동기 냉매, 다용도 용제 제조, 세척제, 발포제, 냉각 제 제조, 플라스틱 산업, 스테인리스강 산업에서 사용하며 중 추신경계에 악영향과 호흡독성을 일으키므로, 노동부 TWA 


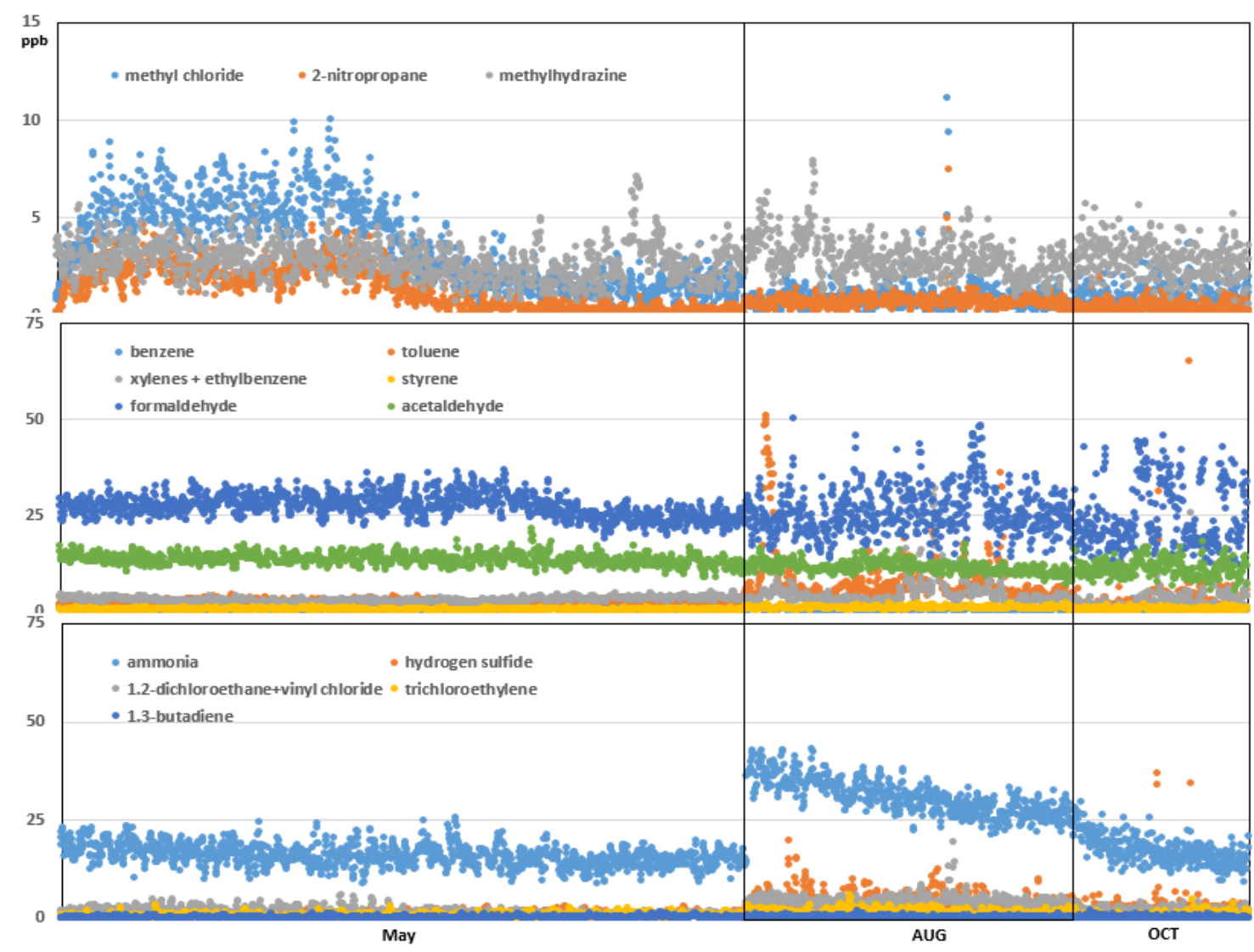

Fig. 6. Variations of hazardous air pollutant concentration in Shinpyeong-Jangrim general industrial complex.

$50 \mathrm{ppm}$ 으로 관리하고 있다. VOCs의 특징처럼 5 월에 높은 농 도로 나타났다. 포름알데하이드의 경우 8월과 10 월에 변화폭 이 증가하였는데, 이는 계절적 온도상승에 따른 작업장별 환 기량 변화에 의한 것으로 판단된다. 메틸클로라이드와 같은 알칸계열인 2-나이트로프로페인은 살균보존제, 유기용매로 사용되며 평균 $1.00 \mathrm{ppb}$ 로 사상공업지역 평균 $0.72 \mathrm{ppb}$, 배경 농도 평균 $0.12 \mathrm{ppb}$ 보다 높게 측정되었고, 메틸클로라이드와 유사한 월별 농도변화를 나타내었다. 아민계열인 메틸히드라 진은 환원제, 용매, 화학물질 합성 중간체로 사용되며, 월간 변화없이 유사한 농도값으로 조사되었다. 암모니아, 황화수 소, 톨루엔은 전반적으로 기온이 상승하는 8월에 높은 값으 로 측정되었으며, 그 외 물질들은 유사한 농도값으로 조사 되었다.

신평·장림일반산업단지를 대기이동측정시스템으로 이동하 면서 SIFT-MS로 측정한 유해대기오염물질 농도를 지리정보시 스템(GPS) 자료와 연계하여 오염지도를 Fig. 7에 나타내었다. 배출원에 따라 고농도 지점이 표시되었으며, 남쪽 무지개공 단 보다 염색폐수처리장이 있는 북쪽 지점이 비교적 오염도가 높은 것으로 나타났다. 포름알데하이드와 아세트알데하이드 는 부산환경공단 강변사업소와 동성화학 인근으로 높게 나타 났으며, 암모니아의 경우 가락타운 인근 지점의 농도가 높아 지속적인 관리가 필요할 것으로 판단된다. 염화비닐, 트리클
로로에틸렌은 무지개공단 쪽의 오염도가 약간 높은 경향을 나타내었으며, PM-10은 신평·장림일반산업단지 전 지역이 유사하였으나, PM-2.5의 경우 남쪽 무지개공단쪽이 높은 농 도로 나타났다.

SIFT-MS 분석물질 86종, OPC 분석물질 2종의 농도분포 상 관관계를 조사하여 $80 \%$ 이상의 상관도를 보이는 물질 그래프 를 Fig. 8에 나타내었다.

살균보존제, 살충제, 유기용매로 사용되는 우레탄과 2-나이 트로프로페인은 사상공업지역 $\mathrm{R}=0.8722025790$ 상관도를 보였으며, 신평·장림일반산업단지에서도 $\mathrm{R}=0.918094964$ 로 높은 상관도를 나타내었다. 그 외 메틸-t 뷰틸에테르와 프로피 온알데하이드+프로필렌옥사이드 $84.2 \%$, 톨루엔과 아닐린 $85 \%$ 로 사상공업지역과 유사하게 높은 상관관계를 나타내었 다. 그러나, 뷰틸알데하이드는 사상공업지역에서와는 다르게 1.2 -에폭시부탄과 $86 \%$ 의 높은 상관관계로 조사되었다.

GPS 좌표와 연계한 PM-2.5 농도분포 상관관계는 사상공업 지역과 마찬가지로 $\mathrm{NH}_{3}$ 및 VOCs 물질별 농도분포와 낮은 상관관계로 나타났으며, 발레르알데하이드(Pentanal)가 86종 중 $\mathrm{R}=0.232329232$ 로 가장 높은 값으로 평가되었다. 사상공업 지역과 동일하게 고정지점에 의한 측정이 아니라 차량을 이용 한 이동측정값이므로 향후, 대기 중 VOCs가 미세먼지 2차 생성 전구물질로써의 기여도를 파악하기 위하여는 VOCs 오 


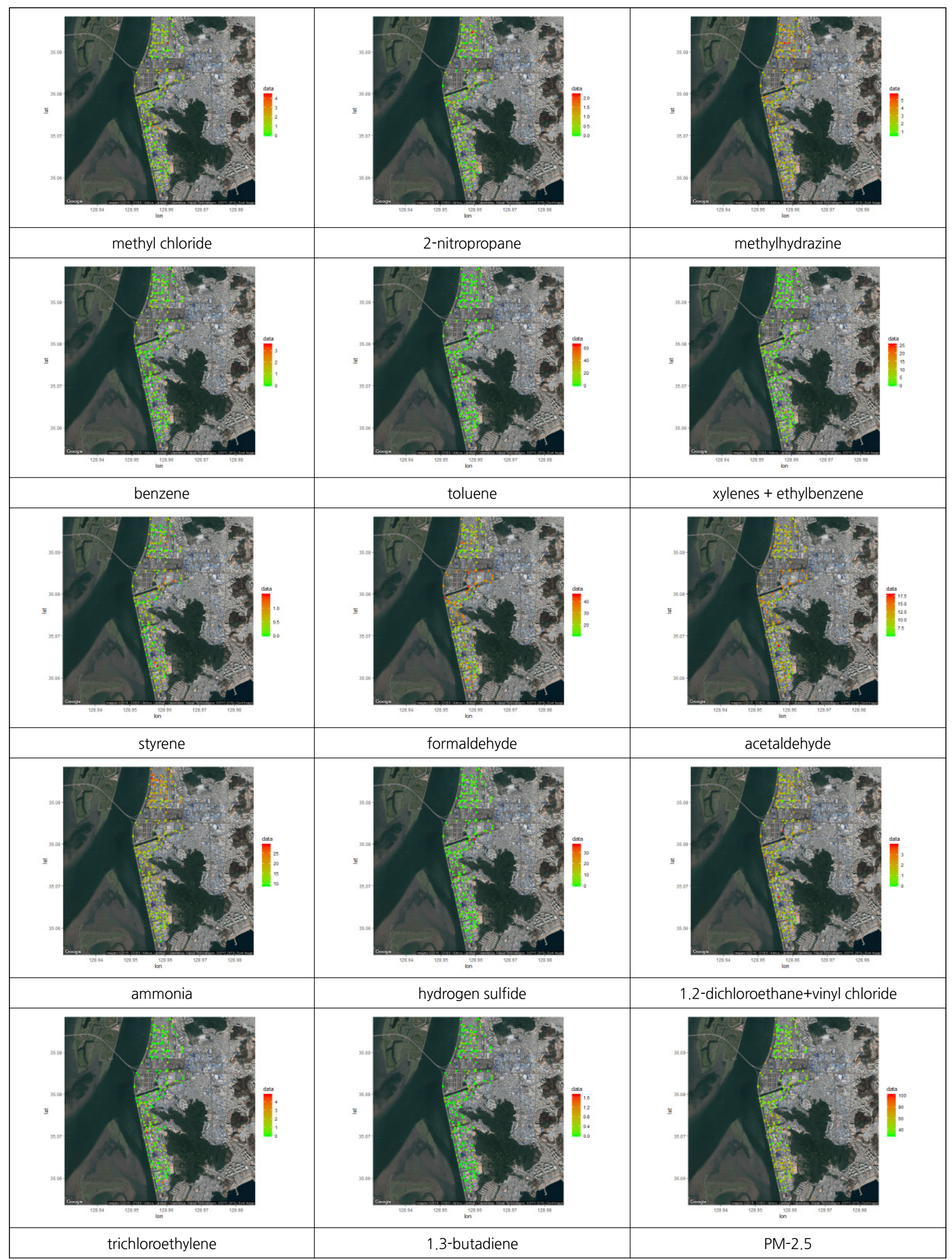

Fig. 7. Map of hazardous air pollutant concentration in Shinpyeong-Jangrim general industrial complex. 


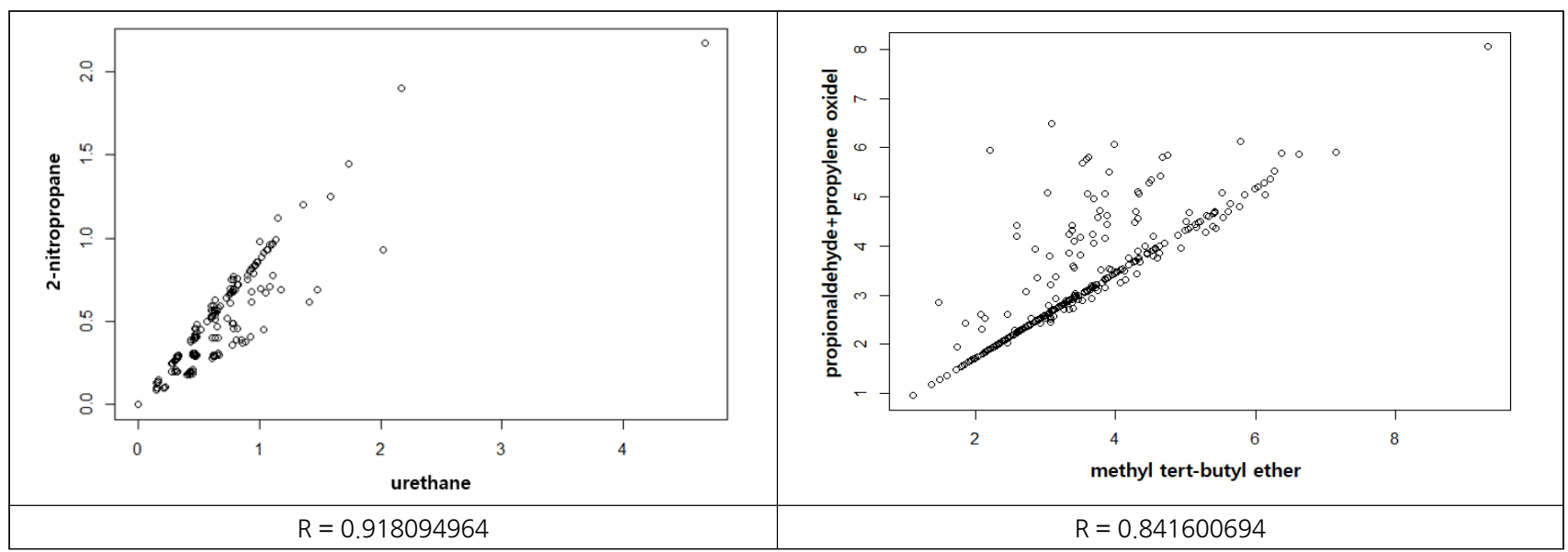

Fig. 8. Scatter plot of hazardous air pollutants in Shinpyeong-Jangrim general industrial complex.

염도가 높은 지점을 고정지점으로 선정하여 추가연구가 필요 할 것으로 판단된다.

\section{4. 결론}

$\mathrm{VOCs}$ 등 대기오염물질의 연속 실시간 측정가능한 SIFT-MS를 활용하여 사상공업지역과 신평·장림일반산업단 지 주변 환경영향을 조사하고, 산업단지 주변 대기오염물질 오염지도를 작성하여 주요 영향 물질을 파악하고자 하였으며, 다음과 같은 결과를 얻을 수 있었다.

1. 대기환경기준 물질인 벤젠은 모두 대기환경기준 이내이 며, 헥산이 최고농도로 나타났다.

2. SIFT-MS 84종, OPC 2종 분석결과 사상공업지역이 신 평-장림일반산업단지 보다 대부분 항목이 상대적으로 높은 농도값을 나타내었다.

3. 사상공업지역은 알칸, 알데하이드, 알콜계열의 화학물질 이 상대적으로 높게 나타났고, 신평·장림일반산업단지는 아 미드, 티올계열의 화학물질이 상대적으로 높게 나타났다.

4. VOCs 대부분은 5 월에 높게 측정되었고, 일부 악취물질 은 여름에 높게 측정되었다.

5. 사상공업지역의 오염지도는 낙동대로와 감전천 주변의 오염도가 높게 나타났고, 신평·장림일반산업단지의 오염지도 는 배출원에 따라 다양하게 나타났으나, 염색폐수처리장이 있 는 북쪽지점이 상대적으로 높게 나타났다.

6. PM-2.5와 VOCs 농도분포의 상관관계는 낮은 값으로 조 사되었고, 도로를 이용한 이동측정 보다 고정지점을 통한 추 가연구가 진행되어야 할 것으로 판단된다.

\section{Acknowledgement}

이 연구는 환경부 국립환경과학원 환경분야시험검사의 국 제적 적합성기반구축사업비 지원으로 수행되었습니다.

\section{References}

1. Korea Industrial Complex Corporation, National industrial complex status statistics table, http://www.kicox.or.kr, April (2021).

2. United States Environmental Protection Agency, Category for persistent, bioaccumulative and toxic new chemical substances, Federal Register, 64, 60194-60204(1999).

3. S. O. Baek, C. G. Jeon, Current status and future directions of management of hazardous air pollutants in Korea-focusing on ambient air monitoring issues, J. Korean Soc. Atmos. Environ., 29(5), 513-527(2013).

4. S. Krol, B. Zabiegala, J. Namiesnik, Monitoring VOCs in atmospheric air II. Sample collection and preparation, Trend. Anal. Chem., 29(9), 1101-1112(2010).

5. D. Smith, P. Spanel, Selected ion flow tube mass spectrometry(SIFT-MS) for on-line trace gas analysis, Mass Spectrometry Rev., 24(5), 661-700(2005).

6. N. K. Sharma, M. Choct, S. Wu, R. A. Swick, Nutritional effects on odour emissions in broiler production, Poult. Sci. J., 73(2), 257-280(2017).

7. P. Pakanat, S. Barringer, The effect of food additives in fruit drinks on the nosespace using selected ion flow tube mass spectrometry (SIFT-MS), J. Food Agri., 1(1), 1-10(2016).

8. J. Dummer, M. Storer, M. Swanney, M. McEwan, A. S. Thomas, S. Bhandari, S. Chambers, R. Dweik, M. Epton, Analysis of biogenic volatile organic compounds in human health and disease, Trend. Anal. Chem., 30(7), 960-967(2011).

9. P. Spanel, D. Smith, Progress in SIFT-MS: breath analysis and other applications, Mass Spectrom. Rev., 30(2), 236-267(2011).

10. B. C. Shin, J. W. Park, S. J. Song, H. J. Lee, J. W. Cha, $\mathrm{S}$. B. $\mathrm{Ru}$, Accuracy evaluation and analysis of OPC measurement data, Natonal Institute of Meteorological Sciences Technology Note(2016).

11. Korean Society for Atmospheric Environment, Monitoring of hazardus air pollutants in the industrial area(IV), National 
Institute of Environmental Research(2018).

12. L. Cheng, L. Fu, R. P. Angle, H. S. Sandhu, Seasonal variation of volatile organic compounds in Edmonton, Alberta, Atmos. Environ., 31(2), 239-246(1997).

13. J. Y. Ahn, C. S. Kim, B. R. Jung, G. Ok, Formation and safety supervision of hazardous air pollutants(HAPs) by combustion of firecracker, J. Korean Soc. Environ. Analysis, 9(3), 151-163(2006).

14. Y. G. Lee, J. Y. Jeong, H. B. Lim, J. Y. Kim, The characteristics of ambient air VOCs concentration in Kyonggi area, J. Korean Soc. Environ. Analysis, 2(4), 261-266(1999).

15. Busan Metropolitan City, Air quality action plan of Busan, Busan Metropolitan City(2002).

16. N. K. Moon, J. H. Seo, Analysis system for regional environmental status to support environmental assessment: estimation of PM-2.5 contribution and conversion rates by source category over local gevemments, Korea Environment Institute, Sejong, Republic of Korea, pp. 1-140(2018).

\section{Declaration of Competing Interest}

The authors declare that they have no known competing financial interests or personal relationships that could have appeared to influence the work reported in this paper.

\section{Authors and Contribution Statement}

\section{Seongwoo Choi}

Busan Metropolitan City Institute of Heaith \& Environment, Researcher, ORCID(C) 0000-0002-7069-6184: Conceptualization, Data curation, Data analysis, Methodology, Visualization, Writing - original draft, review and editing.

\section{Seungwoo Park}

Busan Metropolitan City Institute of Heaith \& Environment, Researcher, ORCID 다 0000-0002-4158-751X: Data curation, Data analysis.

\section{Youngwook Cha}

Busan Metropolitan City Institute of Heaith \& Environment, Researcher, ORCID (C) 0000-0002-9448-4899: Data curation, Data analysis.

\section{Seoi Lee}

Busan Metropolitan City Institute of Heaith \& Environment, Team manager, ORCID (1) 0000-0001-6537-4132: Conceptualization, Methodology.

\section{Eunchul Yoo}

Busan Metropolitan City Institute of Heaith \& Environment, Department manager, ORCID 시 0000-0003-3101-6892: Conceptualization, Supervision. 